\title{
Pharmaceutico-Analytical Study of Vatavidhvamsana Rasa
}

\author{
Research Article
}

\section{Mahesh $\mathbf{S}^{1}$, Neethu S Pillai², Praveen Kumar K S3 , Dilip Prajapati ${ }^{4}$, Patgiri B J5}

\author{
1, 3, 4. PhD Scholar, 5. Professor and Head of the Department of Rasasastra and Bhaishajya Kalpana, \\ Institute for Postgraduate Teaching and Research in Ayurveda, Gujarat Ayurveda University, Jamnagar, \\ 2. Medical Officer, Regional Research Center of Ayurveda, CCRAS, Port Blair.
}

\begin{abstract}
Vatavidhvamsana rasa (VVR) is a well-known herbo-mineral formulation explained in classical ayurvedic text Yogaratnakara and also quoted in Ayurveda Formulary of India (AFI) and is mainly indicated for Vatika disorders. There is a lack of data regarding the standardization of pharmaceutical process and analytical profile of VVR. Aim: To prepare vatavidhvamsana rasa and analyze it using various physicochemical parameters. Materials and methods: Total three batches of Vatavidhvamsana Rasa was prepared as per the classical method explained in the reference to evaluate the standard procedure. During the pharmaceutical process, all ingredients were mixed thoroughly and triturated thirty times with ten bhavana drugs for an average of 90 hours. The pharmaceutical and analytical parameters were completed and the data was recorded. Results: Three batches of Vatavidhvamsana Rasa after preparation showed an average increase of $12.93 \%$ yield. Pharmacognostical evaluation showed the presence of the ingredients used. Average values of physicochemical parameters of Vatavidhvamsana Rasa were as follows: loss on drying $6.19, \mathrm{pH} 7$, total ash value 36.46 , acid insoluble ash 7.16 , water soluble extractive value 17.24 , alcohol soluble extractive value 7.13. HPTLC of Vatavidhvamsana Rasa revealed a total of 11 and 12 bands at $254 \mathrm{~nm}$ and $366 \mathrm{~nm}$. Conclusion: Data generated from pharmaceutical, analytical studies and HPTLC can be used to develop a preliminary standard profile for the formulation Vatavidhvamsana Rasa.
\end{abstract}

Key Words: Vatavidhvamsana Rasa, HPTLC, Herbominerals, Bhasma, Standardization.

\section{Introduction}

Vatavidhwamsana Rasa(1), a well-known herbo-mineral Ayurvedic preparation mentioned in Yogaratnakara vatavyadhi chikitsa chapter, which has even been quoted at Ayurvedic Formulary of India ${ }^{2}$ and is mainly indicated for Vatika disorders. It contains Shodhita Parada (Purified Hg-Mercury),Shodhita Gandaka (Purified Sulphur,Naga Bhasma (incinerated lead), Vanga Bhasma (Incinerated Tin), Tamra Bhasma (incinerated Copper), Loha Bhasma (incinerated Iron), Abhraka Bhasma (incinerated Mica), and other herbal ingredients. The dose of Vatavidhvamsana Rasa as per the reference is 2 gunja $(250 \mathrm{mg})$.

Drug standardization mainly intended to guarantee the quality, efficacy, and uniformity of the final product (3). So to maintain the quality of the final product in every batch, standardization plays a major role. Quality approved raw materials, proper in-process quality checks and finished product quality checks were important in production. Standardization starts from the

\section{* Corresponding Author:}

\section{Mahesh S}

$\mathrm{PhD}$ scholar,

Department Rasasastra and Bhaishajya Kalpana,

IPGT\&RA, Gujarat Ayurveda university, Jamnagar

Email Id: drmaheshmtg@gmail.com raw drug collection and extends up to the manufacturing of final products. This study aims to develop pharmaceutical standardization of Vatavidhvamsana Rasa (VVR) by preparing three batches as per the classical reference and to establish the quality checking parameters for the formulation.

\section{Aims and objectives}

This study aimed to develop Standard Manufacturing Procedure of Vatavidhvamsana Rasa and to develop analytical profile of Vatavidhvamsana Rasa.

\section{Materials nad methods}

\section{Raw materials collection and authentication}

All the raw drugs both herbal and minerals for the preparation of Vatavidhvamsana rasa (VVR) were collected from the Dept. of Pharmacy attached with the Institute for postgraduate teaching and research for Ayurveda, Gujarat Ayurveda University, Jamnagar. All the raw materials were identified and authenticated by the Pharmacognosy department of the institute authenticated as per the standards of Ayurvedic Pharmacopia of India. The ingredients used were listed below in table 1 and bhavana drugs used were listed in table 2. Three batches of VVR were prepared for standardization viz, VVR 1, VVR 2 and VVR 3 in the Department of Rasashashtra \& Bhaishajya Kalpana, Laboratory, IPGT\&RA, Jamnagar. 


\begin{tabular}{|c|c|c|c|c|}
\hline Sr. No. & Ingredients & Latin Name & Part Used & Composition \\
\hline \multicolumn{5}{|c|}{ Metals / minerals used } \\
\hline 1 & Shodita Parada & Purified Mercury & ---- & 1 Part \\
\hline 2 & Shodita Gandaka & Purified Sulphur & ---- & 1 Part \\
\hline 3 & Vanga Bhasma & Incinerated Tin & ---- & 1 Part \\
\hline 4 & Naga Bhasma & Incinerated Lead & ---- & 1 Part \\
\hline 5 & Tamra Bhasma & Incinerated Copper & ---- & 1 Part \\
\hline 6 & Loha Bhasma & Incinerated Iron & ---- & 1 Part \\
\hline 7 & Abhraka Bhasma & Incinerated Mica & ---- & 1 Part \\
\hline 8 & Shodita Tankana & Purified Borax & ---- & 1 Part \\
\hline \multicolumn{5}{|c|}{ Herbal drugs used } \\
\hline 9 & Pippali & Piper longum Linn. & Dried Fruit & 2 Parts \\
\hline 10 & Shundi & Zingiberofficinale Roscoe. & Dried Rhizome & 2 Parts \\
\hline 11 & Maricha & Piper Nigrum Linn. & Dried Fruit & 1 Part \\
\hline 12 & Shodita Vatsanabha & $\begin{array}{l}\text { Aconitum chasmantum } \\
\text { Staff.ex.Holmes }\end{array}$ & Root tuber & $41 / 2$ Parts \\
\hline
\end{tabular}

Table No.2- Bhavana dravyas of Vatavidhvamsana Rasa

\begin{tabular}{l|l|l|l|l|l|l} 
Sr. No. Ingredients & $\begin{array}{l}\text { Botanical name /Latin } \\
\text { Name }\end{array}$ & Part Used & Form
\end{tabular}

Composition

Three bhavana in each of the following drugs

\begin{tabular}{|c|c|c|c|c|c|}
\hline \multirow[t]{4}{*}{1} & Trikatu & Kwatha of Trikatu & & \multirow{4}{*}{$\begin{array}{l}\text { Kwath } \\
\text { (Decoction) }\end{array}$} & \multirow{4}{*}{ Q.S } \\
\hline & Shundi & Zingiber officinale Roxb. & Dried Rhizome & & \\
\hline & Maricha & Piper nigrum Linn. & Dried Fruit & & \\
\hline & Pippali & Piper longum Linn. & Dried Fruit & & \\
\hline \multirow[t]{4}{*}{2} & Triphala & Kwatha of Triphala & & \multirow{4}{*}{ Kwath (Decoction) } & \multirow{4}{*}{ Q. } \\
\hline & Amalaki & Embilica officinalis Gaertn. & Dried Fruit & & \\
\hline & Bibheetaki & Terminalia bellerica Roxb. & Dried Fruit & & \\
\hline & Hareetaki & Terminalia chebula Retz. & Dried Fruit & & \\
\hline 3 & Shoditha Chitraka & Plumbago zeylanica Linn. & Root & Kwath (Decoction) & \\
\hline 4 & Bhringaraja & Eclipta alba Hassk. & Whole plant & Swarasa (Juice) & \\
\hline 5 & Kushta & Sausserea lappa C.B.Clarke & Root & Kwath (Decoction) & \\
\hline 6 & Nirgundi & Vitex negundo Linn. & Leaf & Swarasa(Juice) & \\
\hline 7 & Arka ksheera & Calotropis procera (Ait.)R.Br. & Latex & Ksheera(latex) & \\
\hline 8 & Bhumi amalaki & Phyllanthus niruri Linn. & Whole plant & Swarasa(Juice) & Q \\
\hline 9 & Chandrasura & Lepidium sativum Linn. & Seed & Kwath (Decoction) & Q \\
\hline 0 & Nimbu Swarasa & Citrus limon (Linn.) Burm.f & Fruit & Swarasa(Juice) & \\
\hline
\end{tabular}

\section{Pharmaceutical study: Method of preparation of Vatavidhvamsana rasa}

Three batches of Vatavidhvamsana Rasa were prepared as per the method of kharaleeya rasayana preparation. The amount of ingredients taken in all the three batches was listed in table-3. All herbal drugs were washed with water and dried and powdered finely. At first, Kajjali (a combination of mercury and sulphur) was prepared by grinding processed mercury and sulphur using mortar and pestle, till it attains a lusterless black fine powder form. Add Naga Bhasma, Loha Bhasma, Vanga Bhasma, Tamra Bhasma, Abhraka Bhasma, processed Tankana powder, Maricha powder, Pippali powder, Shundi powder in the prescribed quantity mentioned in table-3 was added to the kajjali and mixed well using a khalvayantra. After that $90 \mathrm{~g}$ of shodita vatsanabha powder was added and triturated well to form a uniform fine mixture. This is triturated three times each in the following ten media in sufficient quantity (total thirty triturations): 1.Decoction of Trikatu, 2. Decoction of Triphala, 3. Decoction of Chitraka, 4. Juice of Bhringaraja, 5.Latex of Arka, 6. Juice of Nirgundi, 7. Juice of Tamalaki, 8. Decoction of Chandrasoora, 9. Decoction of Kushta and 10. Juice of Nimbu. Duration of each bhavana was 3 hours. Then the final product was dried in shade and stored in an airtight glass container.

Table 3- Quantity of ingredients used in all the three batches of VVR

\begin{tabular}{|c|c|c|c|c|}
\hline \multirow{2}{*}{ Sr. No. } & \multirow{2}{*}{ Ingredients } & \multirow{2}{*}{$\begin{array}{l}\text { Quantity (g) in three batches } \\
\text { VVR 1 }\end{array}$} & \multirow[b]{2}{*}{ VVR 2} & \multirow[b]{2}{*}{ VVR 3} \\
\hline & & & & \\
\hline 1 & Shodita Parada & 20 & 20 & 20 \\
\hline 2 & Shodita Gandaka & 20 & 20 & 20 \\
\hline 3 & Vanga Bhasma & 20 & 20 & 20 \\
\hline 4 & Naga Bhasma & 20 & 20 & 20 \\
\hline
\end{tabular}




\begin{tabular}{|l|l|l|l|l|}
\hline $\mathbf{5}$ & Tamra Bhasma & 20 & 20 & 20 \\
\hline $\mathbf{6}$ & Loha Bhasma & 20 & 20 & 20 \\
\hline $\mathbf{7}$ & Abhraka Bhasma & 20 & 20 & 20 \\
\hline $\mathbf{8}$ & Shodita Tankana & 20 & 20 & 20 \\
\hline $\mathbf{9}$ & Pippali & 40 & 40 & 40 \\
\hline $\mathbf{1 0}$ & Shundi & 40 & 40 & 40 \\
\hline $\mathbf{1 1}$ & Maricha & 20 & 20 & 20 \\
\hline $\mathbf{1 2}$ & Shodita Vatsanabha & 90 & 90 & 90 \\
\hline
\end{tabular}

Table 4: Quantity of bhavana drugs used for the preparation

\begin{tabular}{|c|c|c|c|c|c|}
\hline \multirow[t]{2}{*}{ Sr.No. } & \multirow[t]{2}{*}{ Drugs used } & \multirow{2}{*}{$\begin{array}{l}\text { Time taken for } \\
\text { one bhavana }\end{array}$} & $\begin{array}{c}\text { Batch } 1 \text { bhavana } \\
(\mathrm{ml})\end{array}$ & $\begin{array}{c}\text { Batch } 2 \text { bhavana } \\
(\mathrm{ml})\end{array}$ & $\begin{array}{c}\text { Batch } 3 \text { bhavana } \\
(\mathrm{ml})\end{array}$ \\
\hline & & & \multicolumn{3}{|c|}{ Three bhavana } \\
\hline 1 & Trikatu kwath & 9 hours & 600 & 600 & 600 \\
\hline 2 & Triphala kwath & 9 hours & 540 & 540 & 540 \\
\hline 3 & Chitrak Kwath & 9 hours & 540 & 540 & 540 \\
\hline 4 & Bhringaraj swarasa & 9 hours & 540 & 540 & 540 \\
\hline 5 & Kushta kwath & 9 hours & 540 & 540 & 540 \\
\hline 6 & Nirgundi swarasa & 9 hours & 540 & 540 & 540 \\
\hline 7 & Arka ksheera & 9 hours & 540 & 540 & 540 \\
\hline 8 & Bhumiamalaki swarasa & 9 hours & 540 & 540 & 540 \\
\hline 9 & Chandrasura kwath & 9 hours & 540 & 540 & 540 \\
\hline 10 & Nimbu swarasa & 9 hours & 540 & 540 & 540 \\
\hline
\end{tabular}

\section{Pharmacognostic study}

Pharmacognostic evaluation of the fine powder of final product was in the Pharmacognosy Lab. I.P.G.T.\&R.A., Gujarat Ayurveda University., Jamnagar.

Organoleptic study: Powdered sample of VVR was evaluated for its organoleptic characters including taste, touch, colour and odour.

\section{Microscopic characteristics}

A small quantity of fine powder of VVR was dissolved in distilled water. Few drops from the mixture were spread over the glass slide and covered with a coverslip. Then the slide was microscopically evaluated and microphotographs were taken by using the Carl-Zeiss Trinocular microscope attached with camera (4). The microphotographs of VVR were shown in figure 1.

\section{Analytical study (5)}

Physico-chemical parameters like the determination of $\mathrm{pH}$, loss on drying, total ash value, determination of acidinsoluble ash, determination of water-soluble extractive, determination of alcohol-soluble extractive of three batches of VVR were performed. Analytical study was carried out in the pharmaceutical chemistry laboratory of I.P.G.T. and R.A., Gujarat Ayurveda University, Jamnagar.

\section{High-Performance Thin Layer Chromatography (HPTLC):}

Methanolic extract of VVR was spotted on Precoated Silica Gel GF254 aluminium plate $(20 \mathrm{~cm} \times 10 \mathrm{~cm}$ with $250 \mathrm{~m}$ thickness) using Camag Linomate V sample applicator fitted with a $100 \mu \mathrm{L}$ Hamilton syringe. HPTLC was done to develop a chromatographic pattern of VVR by following the standard procedure with a Camag TLC scanner III in reflectance absorbance mode at $254 \mathrm{~nm}$ and $366 \mathrm{~nm}$ equipped with Win CATS software (v 1.2.1 camag) and the solvent used was Toluene: Ethyl acetate (9:1) v/v (6).

\section{Observations and results}

\section{Pharmaceutical Study:}

The yield obtained after the preparation of three batches were shown in table 5. Total 90 hours of bhavana was carried out and the average gain in the yield of VVR is $12.93 \%$. Total time taken for the mixing and thirty bhavana was approximately 99 hours. 


\section{Table 5: Results of three batches of VVR}

\begin{tabular}{|c|c|c|c|c|c|}
$\begin{array}{c}\text { Batch } \\
\text { code }\end{array}$ & $\begin{array}{c}\text { The total quantity } \\
\text { of ingredients taken } \\
\text { (gm) }\end{array}$ & $\begin{array}{c}\text { Final weight after } \\
\text { 30 bhavana } \mathbf{( g m )}\end{array}$ & $\begin{array}{c}\text { Weight gain after } \\
\text { bhavana } \mathbf{( g m )}\end{array}$ & $\begin{array}{c}\text { \% gain in the final } \\
\text { product }\end{array}$ & $\begin{array}{c}\text { Duration for the } \\
\text { whole process } \\
\text { (Hr.) }\end{array}$ \\
\hline 1 & $350 \mathrm{gm}$ & $400 \mathrm{gm}$ & $50 \mathrm{gm}$ & $14 \%$ & 98 \\
\hline 2 & $350 \mathrm{gm}$ & $395 \mathrm{gm}$ & $45 \mathrm{gm}$ & $12.8 \%$ & 100 \\
\hline 3 & $350 \mathrm{gm}$ & $390 \mathrm{gm}$ & $42 \mathrm{gm}$ & $12 \%$ & 99 \\
\hline Avg. & $350 \mathrm{gm}$ & $395 \mathrm{gm}$ & $45.67 \mathrm{gm}$ & $12.93 \%$ & 99 \\
\hline
\end{tabular}

Pharmacognostical evaluation:

Powdered sample of final product VVR was microscopically evaluated under Carl-Zeiss Trinocular research microscope revealed the presence of starch grains of sundi, disturbed sclerides of amalaki, sclerides of bibheetaki, collapased stone cells of hareetaki, oil globules and fragment fibres of kushta, stone cells of chitraka accumulated by the mineral deposition, simple trichome of nirgundi, disturbed exodermal cells of vatsanabha, black debris of minerals or bhasma uniformly spread all over the finished product. The microphotographs of VVR is displayed in figure 1.

Table 6 : Organoleptic characters of Vatavidhvamsana Rasa

\begin{tabular}{|c|c|}
\hline Characters & Results \\
\hline Rupa (colour) & Brownish black \\
\hline Rasa (taste) & Salty followed by pungent \\
\hline Gandha (Odour) & Aromatic \\
\hline Sparsha ( Consistency) & Fine \\
\hline
\end{tabular}

Figure 1: Microphotographs of Vatavidhvamsana rasa

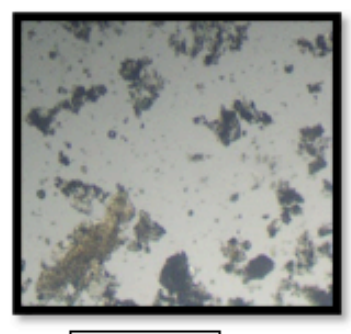

Fig 1 (a)

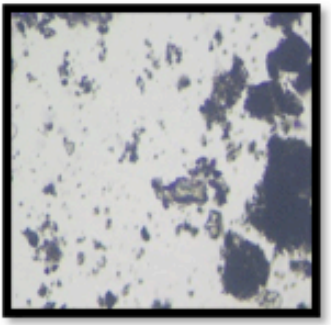

Fig 1 (e)

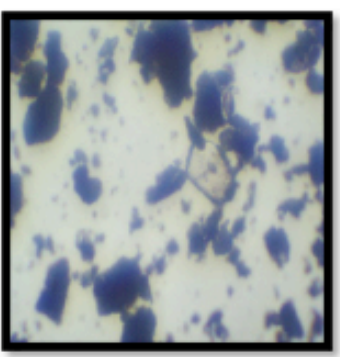

Fig 1 (i)
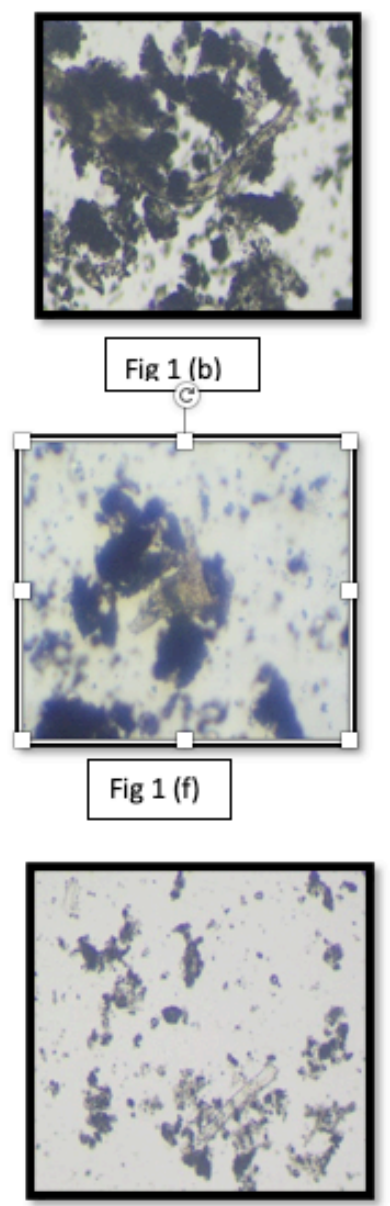

Fig 1 (j)

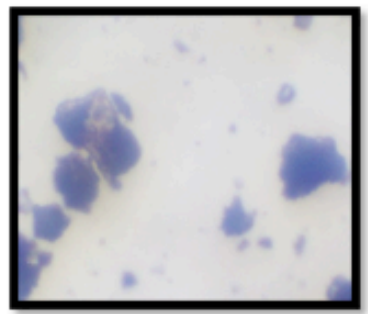

Fig 1 (c)

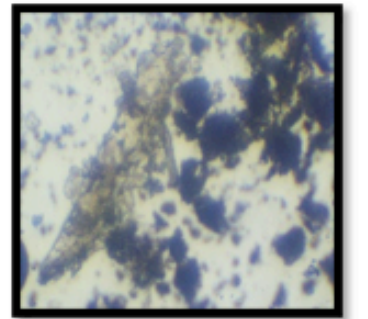

Fig $1(\mathrm{~g})$

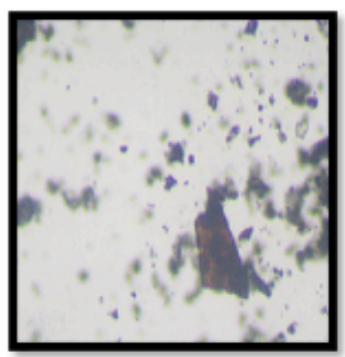

Fig 1 (k)
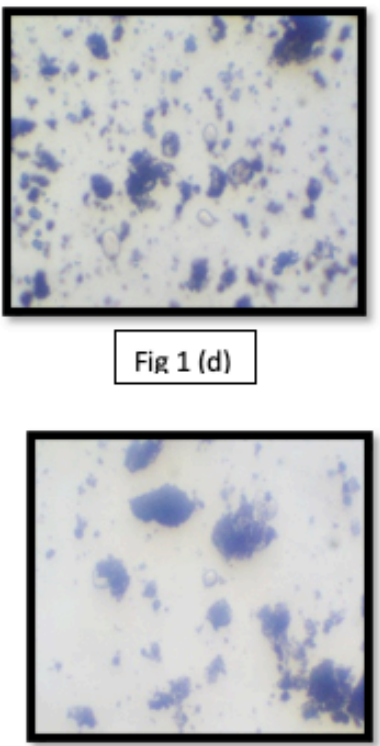

Fig 1 (h)

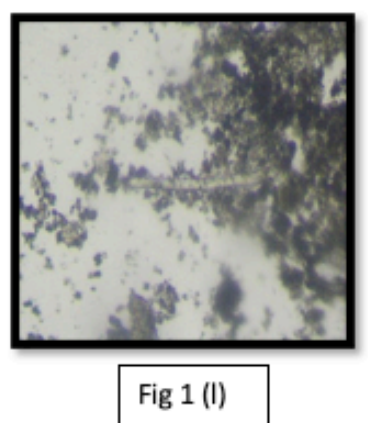

Figure 1: (a). Exodermal cells of Vatsanabha (b). Fibers of Sundi coated with minerals (c).Stone cells of Hareetaki (d).Starch grains of Sundi (e).Silica deposition of amalaki (f).Sclerides of Bibeetaki (g).Sclerides of Amalaki (h).Oil globules of Kushta (i).Trichomes of Nirgundi (j). Fibers of Kushta (k). Tannin content of Chitraka (1). Trichomes of 


\section{Analytical study}

Physicochemical evaluation of all the three samples of VVR was carried out and the data was arranged in table 7. HPTLC evaluation revealed eight common spots in 254 and $366 \mathrm{~nm}$ (Table 8 and Figure 2(a),2(b),2(c)).

Table 7: Results of the physicochemical evaluation of samples of VVR

\begin{tabular}{|l|c|c|c|c|}
\hline \multirow{2}{*}{\multicolumn{1}{|c|}{ Parameters }} & \multicolumn{3}{|c|}{ Results } & \multirow{2}{*}{ Average } \\
\cline { 2 - 4 } & VVR 1 & VVR 2 & VVR 3 & 4.19 \\
\hline Loss on drying at 110 (\%w/w) & 4.02 & 4.56 & 4 & 36.46 \\
\hline Total ash (\%w/w) & 36.13 & 37.25 & 36 & 7.16 \\
\hline Acid insoluble ash (\%w/w) & 7.25 & 7.15 & 7.08 & 7 \\
\hline pH of 5\% aqueous solution & 7 & 7 & 7 & 17.24 \\
\hline Water soluble extractive (\%w/w) & 17.12 & 17.53 & 17.09 & 7.13 \\
\hline Alcohol soluble extractive (\%w/w) & 7.1 & 7.2 & 7.1 & \\
\hline
\end{tabular}

Table 8: Results of HPTLC of all samples of VVR

\begin{tabular}{|c|c|c|c|}
\hline \multirow{2}{*}{ Max Rf values } & Batch & $\mathbf{2 4 5} \mathbf{~ n m}$ & $\mathbf{3 6 6} \mathbf{~ n m}$ \\
\hline & VVR 1 & $0.02,0.26,0.30,0.32,0.41,0.49,0.54$, & $0.03,0.26,0.31,0.36,0.41,0.45$, \\
& & $0.77,0.83,0.16,0.40$ & $0.54,0.77,0.83,0.17,0.73,0.43$ \\
\hline & VVR 2 & $0.02,0.26,0.30,0.32,0.41,0.49,0.54$, & $0.03,0.26,0.31,0.36,0.41,0.45$, \\
& & $0.77,0.83,0.16,0.40$ & $0.54,0.77,0.83,0.17,0.73,0.43$ \\
\hline \multirow{2}{*}{ No. of spots } & VVR 3 & $0.02,0.26,0.30,0.32,0.41,0.49,0.54$ & $0.03,0.26,0.31,0.36,0.41,0.45$ \\
& VVR 1 & $0.77,0.83,0.16,0.40$ & $0.54,0.77,0.83,0.17,0.73,0.43$ \\
\hline & VVR 2 & 11 & 12 \\
\hline & VVR 3 & 11 & 12 \\
\hline
\end{tabular}

Figure 2: 3 Dimensional HPTLC images of showing the Rf values at $254 \mathrm{~nm}$ and $366 \mathrm{~nm}$ Of samples VVR1, VVR2 and VVR3

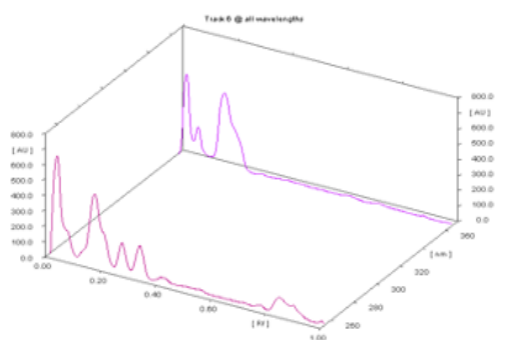

Figure 2(a)- VVR1

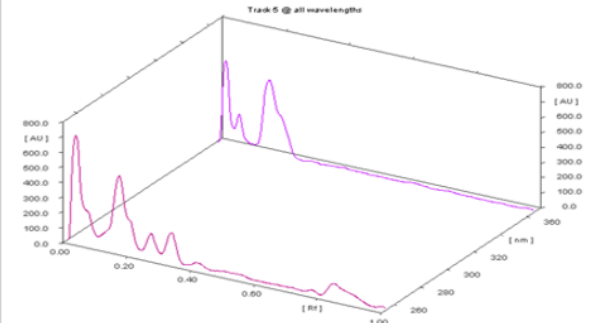

Figure 2(b) VVR 2

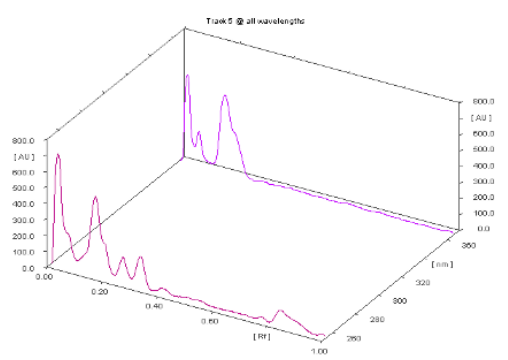

Figure 2(c) VVR 3

\section{Discussion}

VVR was prepared as per the method explained in Yogaratnakara. The formulation consisted of eight eight bhasmas and four herbal drugs, which are properly collected and authenticated. The drug was prepared as per the classical method of preparation of kharaleeya rasayana in which the drugs are properly levigated using various bhavana dravyas. Three batches of VVR prepared showed the average percentage gain is $12.93 \%$ and this increase in gain is due to the thirty bhavana using ten herbal drugs. These bhavana reduces the particle size of the final product and increases the bioavailability of the formulation $(7,8)$. The final product was analyzed for organoleptic characters, pharmacognosy and various quality checks of standardization as per Ayurveda Pharmacopeia of India. The characteristic brownish-black colour of the final product was obtained due to the repeated bhavana with various herbal juices and decoctions. The pharmacognosy evaluation showed the presence of distorted stone cells, sclerides, trichomes of various ingredients and bhavana dravyas. Thirty bhavana collapsed various plant structure and increases the bioavailability.

To validate the pharmaceutical process these different physicochemical parameters were used. Decreased loss on drying showed less chance of microbial contamination and the quality of the final product. Less moisture content, in turn, showed the stability of VVR. The high total ash value is due to the presence of various inorganic salts and metallic ingredients in the final product. This high value is a good indicator of the stringent pharmaceutical processes involved to justify the identity and quality of the final product. Acid insoluble ash value showed the percentage of insoluble inorganic contents of VVR in acids (9). This is also a good indicator to justify the identity of the product. The high water-soluble value 
can be due to the presence of various herbal drugs in the herbomineral product indicating the solubility of formulation in water (10). It also signifies the presence of phytochemicals such as sugar and inorganic compounds. $\mathrm{pH}$ values are nearly neutral in all the three samples which shows the neutral nature of the final product. Neutral $\mathrm{pH}$ may be due to the presence of alkaline and acidic nature of various ingredients. Borax is alkaline and previous studies observed the $\mathrm{pH}$ of naga bhasma was almost alkaline (11). Previous studies showed the acidic nature of kajjali (12) and vatsanabha (13). Since there are no standard records for comparing the analytical values of VVR, every analytical test was repeated for three times to reduce the errors for samples VVR1, VVR 2 and VVR 3. HPTLC analysis of all the samples of VVR was carried out under 254 and $366 \mathrm{~nm}$ wavelengths. It showed 11 spots in $254 \mathrm{~nm}$ and 12 spots in $366 \mathrm{~nm}$ in all samples and eight $\mathrm{Rf}$ values are common in both wavelengths.

\section{Conclusion}

This study deals with the pharmaceutical, pharmacognostic and physicochemical evaluation of VVR. Final product sample of VVR was fine, brownish black in colour with an aromatic smell and salty taste followed by pungent. The pharmacognostic evaluation indicated the presence of various distorted ingredients of VVR due to thirty repeated bhavana for 90 hours. Physico-chemical analysis help to generate a preliminary standard analytical profile for VVR as there is no standard for VVR is available in the pharmacopoeia. So data generated by this study can be used as a tool for the identity and purity of the formulation Vatavidhvamsana Rasa.

\section{Financial support}

Financially supported by IPGT \& RA, Gujarat Ayurveda University, Jamnagar, Gujarat.

\section{Conflicts of interest}

There are no conflicts of interest.

\section{References}

1. Indradev Tripathi, Yogaratnakara of Vaidya lxmipati sastri, $1^{\text {st }}$ edition.Chaukamba Krishnadas Academy Varanasi;1998. 436-437p.

2. Anonymous. The Ayurvedic Formulary of India. $1^{\text {st }}$ ed. The Ministry of Health and Family Welfare,
Dept. of Indian systems of Medicine and Homoeopathy, Part II. New Delhi: Churna Paribhasha Prakaran; 2000. 76p.

3. Vaidya VN, Tatiya AU, Elango A, Kukkupuni SK, Vishnuprasad CN. Need for comprehensive standardization strategies for marketed Ayurveda formulations. J Ayurveda Integr Med.2018;9;312-315.

4. Trease and Evans, Pharmacognosy, 15th Ed., W.B. Sunders Company Ltd; 1996. 569-570p.

5. Lohar DR. Protocol for Testing Ayurvedic, Siddha and Unani Medicines, Government of India Department of AYUSH. Ghaziabad: Ministry of Health and Family Welfare, Pharmacopoeial Laboratory for Indian Medicines;2016. 21p.

6. Reich E, Schibii A; High Performance- Thin Layer Chromatography for the analysis of medicinal plants. Germany: Thieme medical publishers. Inc. 2007; p.129-60.

7. Madhulika priya, Govinda sharma. Critical review on importance of Bhavana in Rasoushadhi. IAMJ.2014;2(4);451-455

8. Sujata K, Reshma S. Bhavana samskara makes the medicine perfect. ejbps,2018;5(10);157-161.

9. Mahesh S, Sheela karalam, Jacob M Titus. Comparative Quality Control Evaluation of Market samples and Classically Prepared Samples of Chyavanaprasa. Int J Ayu Pharm Chem.2018;9(2);118-120

10. Ila Tanna,S. M. S. Samarakoon,H. M. Chandola,V. J. Shukla.Physico-chemical analysis of a Herbomineral compound Mehamudgara vati - A pilot study. Ayu journal.2011;32(4);572-575.

11. Dhirajsingh S Rajput,Rohit A Gokarn,Shukla VJ,Patgiri BJ.Pharmaceutical standardization of naga bhasma (incinerated lead) prepared by using herbal media. Ayurpharm Int J Ayur Alli Sci.2013;2(7);212-223

12. Dani M,Belge R,Tumme D,Dongre V,Pathak M .Physico-chemical analysis of samagunabalijarita kajjali - an ayurvedic drug. WJPR.2017;6(4);836-839

13. Neha Arya, Hemant Kumar. Comparative physicochemical profile of 'vatsanabha' (Aconitum ferox, Ranunculaceae) mula processed through cow's urine and cow's milk. Int. J. Res. Ayurveda Pharm. 2017;8(5);217-222. 